\section{Guatemalan forensic work brings award and death threats}

Jim Giles, Seattle

"I like Bournemouth," says Fredy Peccerelli of his temporary home, a genteel town on England's south coast. "No one has tried to kill me yet."

In his native Guatemala, death threats were a regular occurrence for Peccerelli, a forensic anthropologist who has spent most of the past decade exhuming bodies from mass graves - the legacy of Guatemala's 35 years of conflict.

Peccerelli got international recognition for his work on 14 February, when he received a human-rights award at the annual conference of the American Association for the Advancement of Science (AAAS) in Seattle.

He is now taking a break to study for a masters degree in anthropology at the University of Bournemouth. But he thinks that the work in Guatemala has only just begun. "In 12 years we have investigated 400 cases and exhumed around 3,000 bodies," he says. "There is enough work for another 25 years."

At least 200,000 people are thought to have been killed in Guatemala during fighting between government forces and left-wing insurgents from the early 1960 s to the mid-1990s. Once the conflict receded, Peccerelli, who studied anthropology at Brooklyn College, New York, jumped at the chance to tackle his homeland's problems.

Using funding from charities and the AAAS, the Guatemalan Forensic Anthropology Foundation began responding to requests from rural communities that want to prosecute military officers alleged to have massacred innocent villagers.

The foundation gathers evidence on the attacks and then exhumes the bodies. By determining the cause of death and matching the remains with details of those who have disappeared, Peccerelli's team helps to inform government officials charged with investigating the attacks.

In Guatemala, Peccerelli travels with a bodyguard, as does his family. "I've woken up to find bullet holes in my garage door," he recalls. Other members of his team have been threatened at gunpoint.

Peccerelli is considering further academic studies, although he continues to raise money to keep the investigations going. "I need some stability in my life," says Peccerelli. "I might have to change my work for my own sanity."

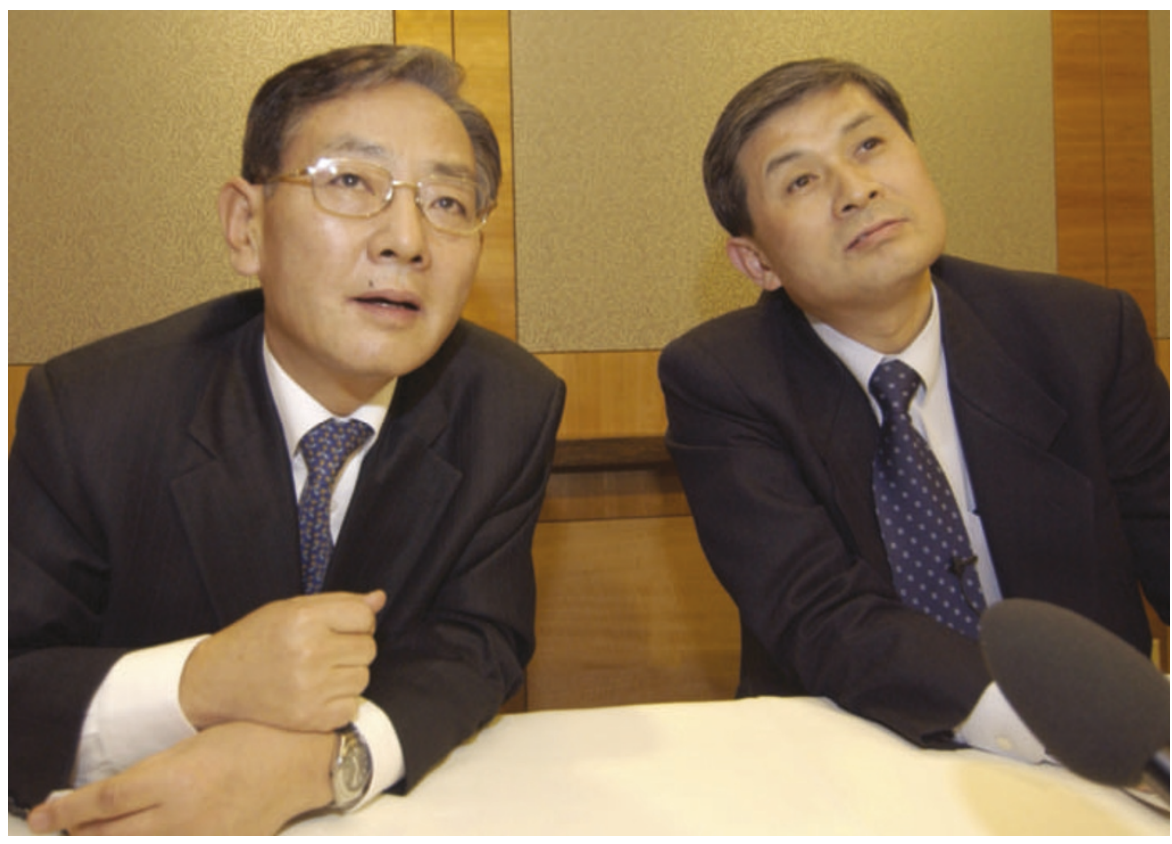

Healthy culture: Koreans support stem-cell research, say Shin Yong Moon (left) and Woo Suk Hwang.

\title{
Cloning success marks Asian nations as scientific tigers
}

\section{Helen Pearson, Seattle}

The successful cloning of human embryos by a South Korean team has alerted Western researchers to the pace of scientific and technological progress in East Asia, biologists say.

A team led by Woo Suk Hwang and Shin Yong Moon of Seoul National University last week revealed that they had grown the first embryonic stem-cell line derived from a cloned human embryo (W. S. Hwang et al. Science 10.1126/science.1094515).

Although the lead researchers are already renowned in their own country for their cloning and stem-cell work, the result has highlighted research in nations such as South Korea and Singapore. "Asian workers are likely to be major players in this field," predicts stem-cell pioneer Roger Pedersen of the University of Cambridge, UK.

Hwang and Moon attribute their success to a supportive cultural environment, wellfunded laboratories, and legislation that permits the cloning of human embryos for research.

Hwang adds that the rarity of organ donation in South Korea lends impetus to research that might create alternative sources of transplant tissue. The work ethic in the labs also helps, he says: "There is no Saturday, no Sunday and no holidays," he told the annual meeting of the American Association for the Advancement of Science (AAAS) in Seattle on 16 February.

Critical to the researchers' success was their collection of 242 eggs from 16 female volunteers, with which they fine-tuned the tricky cloning method. They injected the nucleus from one of the cumulus cells that nestles around a woman's eggs into an egg that had been stripped of its genetic material. About a quarter of the embryos grew into blastocysts, and the team extracted and grew embryonic stem cells - which can generate many different tissues - from one of these.

While lauding the advance, some at the AAAS meeting said that the pace of human therapeutic cloning research in Asia and elsewhere threatens to leave US scientists stranded, as they cannot get federal funds to derive stem cells from human embryos.

But some US biologists say that they can contribute to the field by collaborating with researchers in South Korea, Britain and other countries where the work is supported. "We should behave in a complementary manner," says Gerald Schatten, who studies primate cloning at the University of Pittsburgh. "We don't have to do everything in every country."

The cloning breakthrough has revived public debate in the United States on whether such research should be taking place. There is no US legislation on human cloning because of a stalemate between those who want to outlaw all forms of human cloning and those who want to ban reproductive cloning but allow therapeutic cloning. Because the question is linked to abortion, it could well emerge as an issue in this year's presidential election campaign, specialists at the meeting said. 